\title{
VARITATION OF STOMATAL CHARACTERISTICS IN BROAD LEAVED SPECIES BASED ON HABITAT
}

\author{
Yigit, N. ${ }^{1}-$ Cetin, M..$^{2 *}$ - OZTURK, A. ${ }^{1}-$ SEviK, H. $^{3}-$ Cetin, S. ${ }^{4}$ \\ ${ }^{I}$ Department of Forest Engineering, Faculty of Forestry, Kastamonu University, Kastamonu, \\ Turkey
}

${ }^{2}$ Department of Landscape Architecture, Faculty of Engineering and Architecture, Kastamonu University, Kastamonu, Turkey

${ }^{3}$ Department of Environmental Engineering, Faculty of Engineering and Architecture, Kastamonu University, Kastamonu, Turkey

${ }^{4}$ Department of Landscape Architecture, Faculty of Architecture, Adiyaman University, Adiyaman, Turkey

*Corresponding author

e-mail: mcetin@kastamonu.edu.tr; phone: +90-366-280-2920; fax: +90-366-280-2900

(Received 13 ${ }^{\text {th }}$ May 2019; accepted 28 ${ }^{\text {th }}$ Aug 2019)

\begin{abstract}
This research aims to find the habitat-dependent variation of micromorphological characteristics in the leaves of Fraxinus excelsior (European ash), Platanus orientalis (Plane tree) and Tilia tomentosa (Silver lime) collected from 6 different cities of different climates. The leaves were collected in Turkey in the cities of Rize, Samsun, İzmir, Antalya, Sivas, and Ankara. Samsun and Rize fall under the Black Sea climate region, Ankara and Sivas under the continental climate, whereas Antalya and İzmir enjoy a Mediterranean climate. Using scanning electron microscopy (SEM) to highlight the visible morphological characteristics of the plant, we hoped to uncover how stress affects the micro-morphological properties of the plant but does not affect its vital functions. Leaf epidermis images were obtained with SEM and stoma width $(\mu \mathrm{m})$, length $(\mu \mathrm{m})$, pore width $(\mu \mathrm{m})$, pore length $(\mu \mathrm{m})$, and density (in an area of $1 \mathrm{~mm}^{2}$ ) measurements were obtained using Image $\mathbf{J}$ (https://imagej.net) software. A Duncan test and variance analysis were performed via SPSS ${ }^{\text {(IBM Analytics) }}$ and the habitat-dependent change of these characteristics was evaluated statistically. Accordingly, we determined that the stomatal characteristics varied depending on the habitat, but trees were affected differently by climate conditions. The micromorphological characteristics on the leaves depending on growth conditions were also investigated.
\end{abstract}

Keywords: cities, various climates, micromorphlogy, SEM, landscape plants, Fraxinus excelsior, Platanus orientalis, Tilia tomentosa

\section{Introduction}

Parallel to the increasing rate of urbanization, destruction of green areas around the world has led to an inevitable and undesirable consequence. Along with increasing urbanization, today's modern individuals with increasing incomes and consciousness have begun to realize the importance of green spaces, and as a result, landscape architecture projects have become an integral part of modern life (Sevik and Cetin, 2016; Sevik et al., 2016; Bozdogan Sert et al., 2019; Cetin et al., 2019; Cetin 2019). Landscape studies gain value in proportion to the plant variety used in the design, and the use of uncommon plants in the design process makes the designs even more valuable. This approach has resulted in growing plants in areas that differ from their natural habitats. So much so that although Turkey is located in a region dominated by three main climate types, similar plants have begun to be grown in all three of the 
climate zones. A frequently encountered issue in landscaping is that plant species are often faced with stress factors due to being grown in areas outside their natural habitats. In addition to the visible morphological characteristics of the plant, stress influences not only the micromorphological features of the plant that are not visible to the naked eye but also their vital functions (Cetin et al., 2017; Cetin et al., 2019; Cetin 2019). However, since the number of researches in this field is insufficient, the level of information on the subject is limited. In fact, the changes that occur on the micromorphological level in plants depending on different growth environments and habitats may provide useful insights in many areas including the stress level to which the plant is exposed, its ability to adapt to the growth environment, and the effect of climatic factors on phenotype (Cetin, 2016; Sevik et al., 2017; Sevik et al., 2019; Cetin et al., 2019; Cetin 2019; Bozdogan Sert et al., 2019).

In landscaping, plants used outside the natural distribution areas often do not show their performance in natural habitats, do not reflect their forms in the natural distribution area, and often remain alone with stress factors. These stress factors affect the plant's visible morphological features as well as micromorphological features that are not visible to the eye. If we can determine how these changes at the micro level change in relation to the climate parameters, we can have a lot of ideas from plant stress levels to adaptation levels. However, in order to determine how these changes in micromorphological characteristics should be interpreted, it is necessary to first determine the conditions under which these changes take shape.

The scope of this research was to find the variation of some micromorphological characteristics according to climate type in Fraxinus excelsior L. (European ash), Platanus orientalis L. (Plane tree) and Tilia tomentosa Moench (silver lime) plants grown in various regions of Turkey dominated by different climate types. The hypothesis of the study: Micromorphological characteristics of individuals grown in regions dominated by different climate properties are shaped depending on climate type.

\section{Material and methods}

This work was conducted on the leaves of Fraxinus excelsior, Platanus orientalis, and Tilia tomentosa species. Among these species, Fraxinus excelsior is generally found in Caucasia, North and South Europe. In our country, its general spreading zone is Northern Anatolia, but it also grows naturally in Hatay. It grows naturally between an elevation of 900-2100 m on the edges of creeks and in mixed forests with deciduous and coniferous leaves, but it is also used in landscaping in nearly the whole of Europe. Platanus orientalis naturally grows in Southeast Europe and Western Asia, and nearly in all regions in our country on banks of streams, riversides, at the bottom of valleys, and on leaky and gravelly slopes up to an elevation of $1100 \mathrm{~m}$ from sea level. It is commonly preferred in landscaping as a dust and noise barrier, and widely used in parks and gardens as an alle tree. The natural habitat of Tilia tomentosa species in the world consists of Southeast Europe and Western Asia. In our country, it grows naturally in the deciduous forests of Western and Northern Anatolia between the elevations of 400$1500 \mathrm{~m}$, but it is also widely used in landscaping thanks to its drought-tolerant characteristic and being an alle tree (Kaya et al., 2009).

Leaf samples of the determined species were collected from individuals in Turkey in the cities of Rize, Samsun, İzmir, Antalya, Sivas, and Ankara (Fig. 1 and Table 1). The patterns were collected from individuals used in landscape architecture arrangements in 
centers of city. Among these cities, Samsun and Rize are located in a region where Black Sea climate type is dominant, Ankara and Sivas are located in a region where Continental climate type is dominant, and Antalya and İzmir are located in a region where Mediterranean climate type is dominant. Ten leaves were sampled form five trees of each species. Although these cities are located in regions where a certain climate type is dominant, there is a great variability between their climatic data (Table 2).

Mature leaf specimens collected during the vegetation season (25 August 2017) were pressed and dried, brought to the laboratory and tested under the electron microscope. Scaled images were obtained of the leaf blade abaxial surface near the midvein using scanning electron microscopy (SEM) and transposed into .jpeg photos for use with Image J software. SPSS ${ }^{\circledR}$ (IBM Analytics), analysis of variance (ANOVA) and a Duncan's test were used to evaluate measurements of stoma width (SW), stoma length (SL), stoma pore width (PW), stoma pore length (PL), and stomatal density (across 1 $\mathrm{mm}^{2}, \mathrm{SDEN}$ ) were evaluated potential statistically significant relationships between the selected characteristics (Fig. 2).

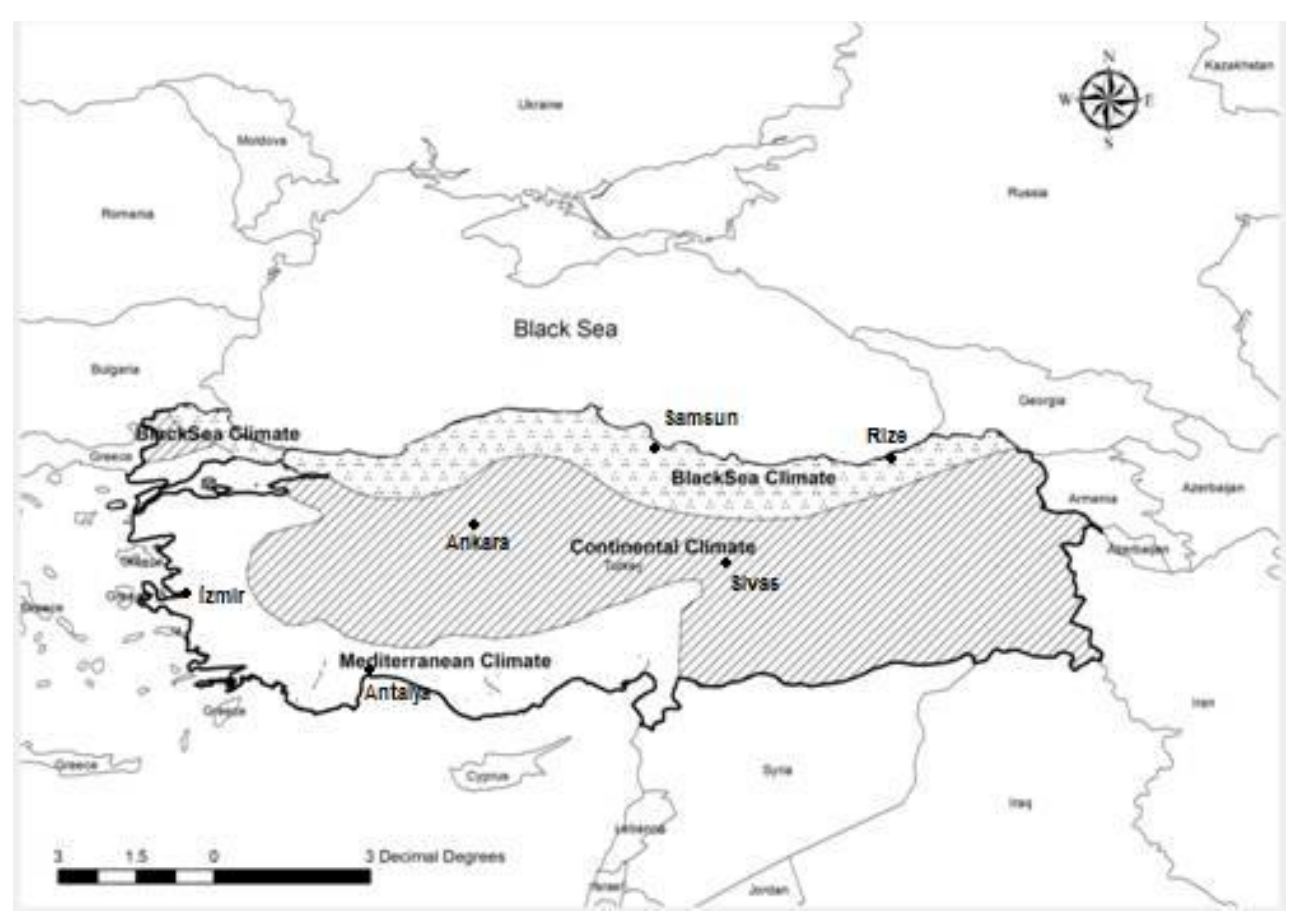

Figure 1. A map indicating the location of each city in Turkey

Table 1. Giving the GPS coordinates of the sampling sites

\begin{tabular}{c|c}
\hline Cities & $\begin{array}{c}\text { Coordinates DMS } \\
\text { (degrees, minutes, seconds) } \\
\text { Latitude N - Longitude E }\end{array}$ \\
\hline Rize & $41^{\circ} 01^{\prime} 34.22^{\prime \prime} \mathrm{N}-40^{\circ} 31^{\prime} 02.34^{\prime \prime} \mathrm{E}$ \\
Samsun & $41^{\circ} 16^{\prime} 49.77^{\prime \prime} \mathrm{N}-36^{\circ} 20^{\prime} 16.14^{\prime \prime} \mathrm{E}$ \\
İzmir & $38^{\circ} 25^{\prime} 05.72^{\prime \prime} \mathrm{N}-27^{\circ} 08^{\prime} 59.84^{\prime \prime} \mathrm{E}$ \\
Antalya & $36^{\circ} 53^{\prime} 49.81^{\prime \prime} \mathrm{N}-30^{\circ} 42^{\prime} 46.70^{\prime \prime} \mathrm{E}$ \\
Sivas & $39^{\circ} 45^{\prime} 05.84^{\prime \prime} \mathrm{N}-37^{\circ} 00^{\prime} 53.45^{\prime \prime} \mathrm{E}$ \\
Ankara & $39^{\circ} 56^{\prime} 19.13^{\prime \prime} \mathrm{N}-32^{\circ} 51^{\prime} 40.11^{\prime \prime} \mathrm{E}$ \\
\hline
\end{tabular}


Table 2. Some climatic data of cities where leaf samples were collected

\begin{tabular}{|c|c|c|c|c|c|c|}
\hline \multirow[b]{2}{*}{ Annual average values } & Antalya & İzmir & Rize & Samsun & Ankara & Sivas \\
\hline & \multicolumn{2}{|c|}{$\begin{array}{c}\text { (Mediterranean climate } \\
\text { type) }\end{array}$} & \multicolumn{2}{|c|}{$\begin{array}{c}\text { (Black Sea climate } \\
\text { type) }\end{array}$} & \multicolumn{2}{|c|}{$\begin{array}{c}\text { (Continental climate } \\
\text { type) }\end{array}$} \\
\hline $\begin{array}{l}\text { Average temperature } \\
\left({ }^{\circ} \mathrm{C}\right)\end{array}$ & 18.6 & 17.8 & 14.3 & 14.5 & 11.9 & 8.9 \\
\hline $\begin{array}{l}\text { Highest average } \\
\text { temperature }\left({ }^{\circ} \mathrm{C}\right)\end{array}$ & 24.1 & 22.6 & 18.0 & 18.2 & 17.8 & 15.3 \\
\hline $\begin{array}{l}\text { Lowest average } \\
\text { temperature }\left({ }^{\circ} \mathrm{C}\right)\end{array}$ & 13.7 & 13.4 & 11.1 & 11.0 & 6.2 & 2.8 \\
\hline $\begin{array}{c}\text { Avg. sunshine duration } \\
\text { (hours/month) }\end{array}$ & 100.3 & 94.5 & 49.4 & 61.0 & 80.3 & 80.5 \\
\hline $\begin{array}{l}\text { Average number of } \\
\text { rainy days }\end{array}$ & 75.1 & 77.7 & 172.5 & 135.6 & 102.3 & 112.5 \\
\hline $\begin{array}{c}\text { Total rainfall } \\
(\mathrm{mm} / \mathrm{yr})\end{array}$ & 1066.9 & 695.9 & 2304.1 & 717.5 & 387.2 & 429.2 \\
\hline $\begin{array}{l}\text { Highest temperature } \\
\left({ }^{\circ} \mathrm{C}\right)\end{array}$ & 45.0 & 43.0 & 38.2 & 39.0 & 41.0 & 40.0 \\
\hline $\begin{array}{l}\text { Lowest temperature } \\
\qquad\left({ }^{\circ} \mathrm{C}\right)\end{array}$ & -4.6 & -8.2 & -7.0 & -9.8 & -24.9 & -34.6 \\
\hline
\end{tabular}

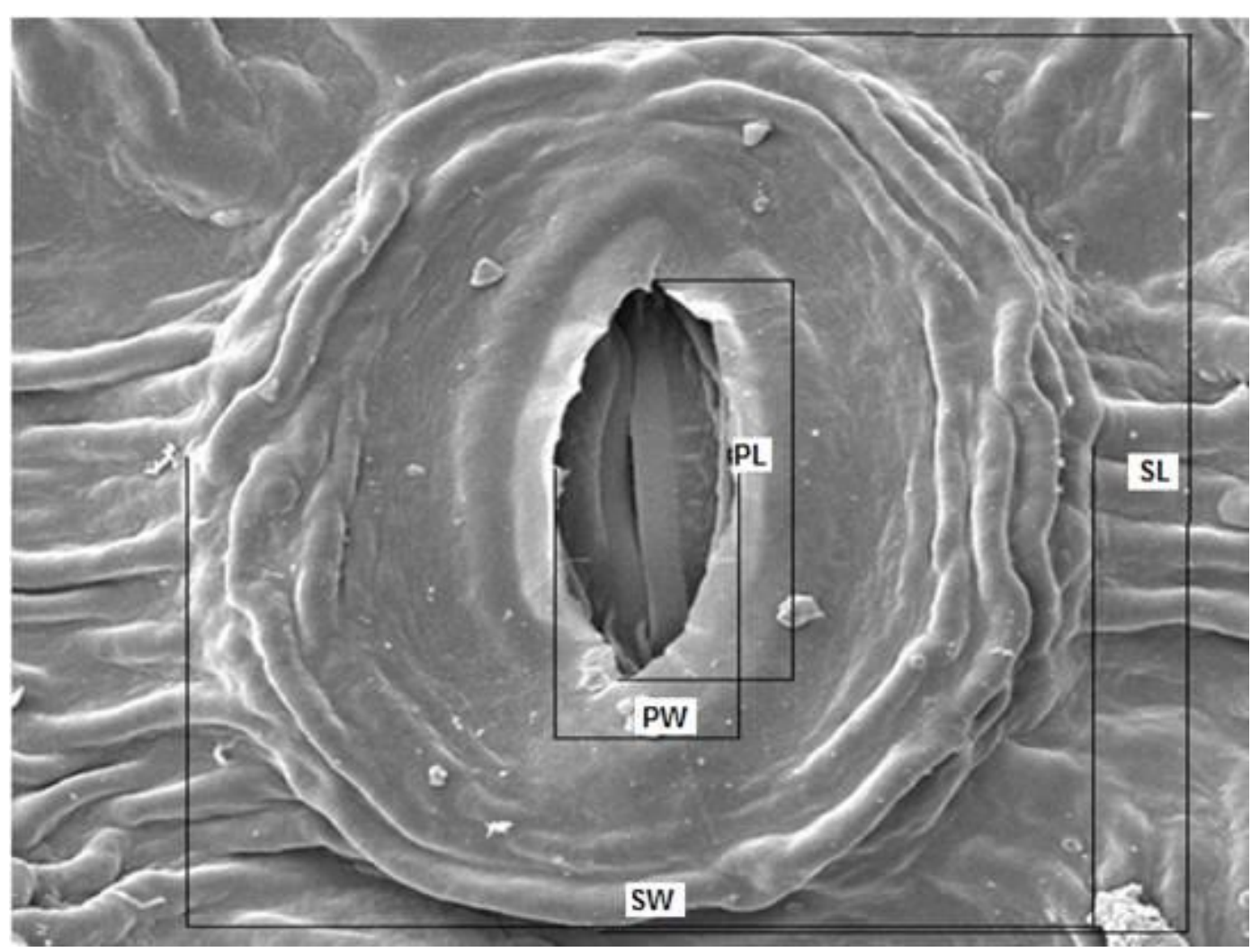

Figure 2. SEM images the representation of the stoma with the width, length, etc. showing exactly where measurements were taken

Data obtained on the micromorphological characteristics were evaluated with SPSS package software, and Duncan test and variance analysis were applied to these data. In 
addition, correlation analysis was performed on the data with the help of SPSS package software in order to determine whether there is a statistically significant relationship between the micromorphological characteristics to be studied.

\section{Results}

City based average values of micromorphological characteristics investigated and the results of the Duncan test and variance analysis applied to these data are presented (Table 3).

Table 3. Variation in leaf micromorphological characteristics based on habitat with species and places responding differently to climatic conditions

\begin{tabular}{|c|c|c|c|c|c|c|}
\hline Species & City & SL & SW & PL & PW & SDEN \\
\hline \multirow{7}{*}{ 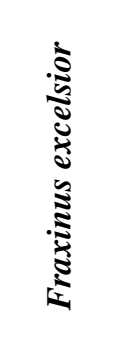 } & Ankara & $25.77 \mathrm{ab}$ & $19.05 \mathrm{~b}$ & $12.57 \mathrm{~b}$ & $6.18 \mathrm{bc}$ & $132 \mathrm{a}$ \\
\hline & Antalya & $26.75 b$ & $19.61 \mathrm{bc}$ & $14.93 \mathrm{c}$ & $5.12 \mathrm{abc}$ & $164 \mathrm{~b}$ \\
\hline & Samsun & $23.06 \mathrm{a}$ & $15.67 \mathrm{a}$ & $9.86 \mathrm{a}$ & $3.97 \mathrm{a}$ & $179 \mathrm{~b}$ \\
\hline & İzmir & $30.00 \mathrm{c}$ & $22.13 \mathrm{c}$ & $13.24 \mathrm{bc}$ & $6.51 \mathrm{c}$ & $262 \mathrm{c}$ \\
\hline & Rize & $33.92 \mathrm{~d}$ & $21.90 \mathrm{c}$ & $19.65 \mathrm{~d}$ & $8.49 \mathrm{~d}$ & $509 \mathrm{~d}$ \\
\hline & Sivas & $24.99 \mathrm{ab}$ & $20.82 \mathrm{bc}$ & $12.40 \mathrm{~b}$ & $4.59 \mathrm{ab}$ & $717 \mathrm{e}$ \\
\hline & F value & $14.674 * * *$ & $8.160 * * *$ & $23.380 * * *$ & $8.418 * * *$ & $928.934 * * *$ \\
\hline \multirow{7}{*}{ 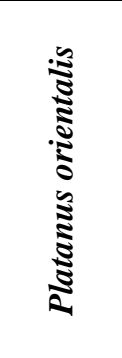 } & Ankara & $31.96 \mathrm{~cd}$ & $25.06 \mathrm{c}$ & $11.59 \mathrm{a}$ & $4.01 \mathrm{~b}$ & $312 \mathrm{~d}$ \\
\hline & Antalya & $25.92 \mathrm{~b}$ & $21.58 \mathrm{~b}$ & $16.12 \mathrm{~b}$ & $4.13 \mathrm{~b}$ & $267 \mathrm{c}$ \\
\hline & Samsun & $34.86 \mathrm{~d}$ & $30.44 \mathrm{~d}$ & $14.12 \mathrm{~b}$ & $5.93 \mathrm{c}$ & $145 \mathrm{~b}$ \\
\hline & İzmir & $27.52 \mathrm{~b}$ & $22.54 \mathrm{bc}$ & $14.18 \mathrm{~b}$ & $6.85 \mathrm{~d}$ & $97 \mathrm{a}$ \\
\hline & Rize & $15.72 \mathrm{a}$ & $10.53 \mathrm{a}$ & $9.96 \mathrm{a}$ & $2.24 \mathrm{a}$ & $309 \mathrm{~d}$ \\
\hline & Sivas & $30.88 \mathrm{c}$ & $24.86 \mathrm{c}$ & $13.99 \mathrm{~b}$ & $5.76 \mathrm{c}$ & $145 \mathrm{~b}$ \\
\hline & F value & $41.110 * * *$ & $39.842 * * *$ & $8.059 * * *$ & $25.710 * * *$ & $294.646 * * *$ \\
\hline \multirow{7}{*}{ 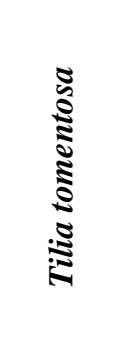 } & Ankara & $18.89 \mathrm{c}$ & $13.40 \mathrm{bc}$ & $10.57 \mathrm{a}$ & $4.23 \mathrm{a}$ & $121 \mathrm{c}$ \\
\hline & Antalya & $15.18 \mathrm{a}$ & $11.95 \mathrm{~b}$ & $10.51 \mathrm{a}$ & $3.53 \mathrm{a}$ & $145 \mathrm{~d}$ \\
\hline & Samsun & $16.01 \mathrm{ab}$ & $14.54 \mathrm{bc}$ & $9.76 \mathrm{a}$ & $3.67 \mathrm{a}$ & $113 \mathrm{c}$ \\
\hline & İzmir & $14.36 \mathrm{a}$ & $9.36 \mathrm{a}$ & $11.26 \mathrm{a}$ & $3.38 \mathrm{a}$ & $176 \mathrm{e}$ \\
\hline & Rize & $17.92 \mathrm{c}$ & $15.07 \mathrm{c}$ & $10.94 \mathrm{a}$ & $3.82 \mathrm{a}$ & $29 \mathrm{a}$ \\
\hline & Sivas & $17.54 \mathrm{bc}$ & $13.97 \mathrm{bc}$ & $10.73 \mathrm{a}$ & $4.35 \mathrm{a}$ & $72 b$ \\
\hline & F value & $7.870 * * *$ & $6.582 * * *$ & $1.826 \mathrm{~ns}$ & $1.441 \mathrm{~ns}$ & $124.119 * * *$ \\
\hline
\end{tabular}

SL, stoma length; SW, stoma width; PL, stoma pore length; PW, stoma pore width; SDEN, stomatal density across $1 \mathrm{~mm}^{2}$. Values with same letter were not significantly different according to a Duncan test. ***Statistically significant at the $\mathrm{p}<0.001$ level of probability

Each value is the average value of 50 leaves, of which 5 are individual leaves

When the results of the study were examined; it was determined that among the three species studies, only Tilia tomentosa did not demonstrate any statistically significant difference between the cities in terms of pore characteristics. All other species showed statistically significant differences among the values obtained from different cities in all characteristics studied at a confidence level of 95\%. For Fraxinus excelsior, the lowest values except for SDEN were obtained in Samsun, and the significantly higher values were obtained in Rize. For SDEN, the lowest values were obtained in Ankara, and 
significantly higher values were obtained in Sivas. For Platanus orientalis, the lowest values except for SDEN were obtained in Rize, and the significantly higher values were obtained in Samsun. For SDEN, the lowest values were obtained in İzmir, and significantly higher values were obtained in Ankara and Rize. In addition, the highest PW value was obtained in Izmir. For Tilia tomentosa, the values obtained in Izmir were in the last homogeneous group for SDEN, while they were in the first homogeneous group for all other characteristics; conversely, the values obtained in Rize were the lowest values for SDEN, whereas the values were in the last homogeneous groups for other characteristics.

According to the results, we concluded that each species give different reactions to climatic demands. For example, while the lowest values for characteristics other than SDEN were obtained in samples collected from Rize for Platanus orientalis, for Tilia tomentosa and Fraxinus excelsior, the significantly higher values for characteristics other than SDEN were obtained in samples collected from Rize. Similarly, for Fraxinus excelsior, the lowest values for all characteristics except SDEN were obtained in Samsun, while the significantly higher values for Platanus orientalis for all characteristics except SDEN were obtained in Samsun. This is the case with most of the characteristics.

Different values were also obtained in the same species for samples gathered from cities located in the same climate zone. For example, in Fraxinus excelsior, the lowest values in all characteristics except SDEN were obtained in Samsun and the significantly higher values were obtained in Rize. In fact, Rize and Samsun are located in areas dominated by the same climate type. A similar situation was also observed in Platanus orientalis.

In order to determine the direction and magnitude of the relationships of the studied characteristics with each other, a correlation analysis was applied to the data and the results of this analysis in Table 4 are given.

Table 4. Relevance of the species characters in relation to the level of each other

\begin{tabular}{c|c|c|c|c}
\hline & SW & PL & PW & SDEN \\
\hline SL & $0.887^{* *}$ & $0.711^{* *}$ & $0.688^{* *}$ & $0.300^{* *}$ \\
SW & & $0.551^{* *}$ & $0.554^{* *}$ & $0.205^{* *}$ \\
PL & & & $0.726^{* *}$ & $0.300^{* *}$ \\
PW & & & & 0.152 \\
\hline
\end{tabular}

Weak correlation (0.10-0.29); moderate correlation (0.30-0.49); strong correlation (0.5-1.0). ** Statistically significant at the $\mathrm{p}<0.01$ level of probability

According to correlation analysis results, it was determined that there is a statistically significant relationship between all characteristics except PW and SDEN. According to Cohen (1988), the relationship between two variables is weak if the value of the correlation coefficient is between 0.10 and 0.29 , moderate if it is between 0.30 and 0.49 , and strong if it is between 0.50 and 1.0. When we take a look at the level of relationship between the characteristics accordingly, we see that there is a weak or moderate relationship between SDEN and other characteristics. While there is a strong relationship between other characteristics, it was found that the strongest relationships were between STL and SW (0.887), and PL and PW (0.726). 


\section{Discussion}

Plants have positive effects such as reducing air and noise pollution in the environments they are in. In addition to these positive effects, they also perform many functions such as reducing wind speed, being an economic resource, and supporting wild life (Kaya et al., 2009; Guney et al., 2016, 2017; Sevik et al., 2016; Cetin and Sevik, 2016; Cetin et al., 2019; Cetin 2019). Used and grown for various purposes in urban centers today, plants are accepted as an indicator of quality and liveability in urban life (Cetin, 2015, 2016; Cetin et al., 2017; Cetin et al., 2019; Cetin 2019).

Plants are living organisms, and fulfilling these functions depends primarily on being grown in areas where optimum climatic and edaphic factors are present for them. Otherwise, plants are exposed to stress conditions, and cannot properly fulfill the functions expected from them. It is therefore a very important matter to determine whether plants are exposed to stress conditions in their growth environment. In landscaping studies, plants are usually exposed to stress factors, depending on whether the plants are used outside their natural habitats. These stress conditions are known to affect the morphological characteristics of the plant. Studies have shown that plant morphological characteristics are influenced by many stress factors such as light (Cetin, 2016; Guney et al., 2016; Cetin et al., 2017), salt stress (Romero-Aranda et al., 2001), and water stress (Ferris et al., 1996). Therefore, it is quite possible that stomatal characteristics are also affected by environmental conditions and especially stress factors (Banon et al., 2004).

Stomata are the most important organelles in terms of leaf activity. Water evaporates from the leaf and stomata control the entry of $\mathrm{CO}_{2}(\mathrm{Xu}$ and Zhou, 2008). The number and size of stomata are significantly affected by environmental factors (Pearce et al., 2006; Galmés et al., 2007; Xu and Zhou, 2008). It has been pointed out in many studies that stoma density, in particular, is affected by environmental conditions and stress factors (Dunlap and Stettler, 2001; Guerfel et al., 2009; Bosabalidis and Kofidis, 2002).

There were significant differences in values obtained in different cities under the same climatic conditions. For example, for Fraxinus excelsior, the lowest values for all characteristics except SDEN were obtained in Samsun, while the significantly higher values were obtained in Rize. In fact, both of these cities are located in a region dominated by the Black Sea climate type. This suggests that microecological conditions may have more impact on leaf micromorphological characteristics. It is known that phenotypic character is the result of the interaction between genetics and the environment, and is shaped by the influence of many environmental factors (Sevik and Cetin, 2015) as well as genetic factors (Yigit et al., 2016). Therefore, genetic and microenvironmental conditions may be more effective on stomatal characteristics.

This situation also explains the fact that species can respond differently to the same climate conditions. As a matter of fact, it has been determined in the study that species do react differently to the same climate type. For example, for Platanus orientalis, the lowest values for all characteristics except SDEN were obtained in samples collected from Rize, whereas for Tilia tomentosa and Fraxinus excelsior the significantly higher values were obtained in samples collected from Rize. This can be explained by the fact that genetic structures of these species are different and therefore they are affected differently from the same climatic type.

It is known that morphological characteristics vary among species depending on many factors, especially origin. Researches have also demonstrated that micromorphological characteristics vary considerably among species (Maiti et al., 2016; 
Galmés et al., 2007). In this case, it is not surprising that different origins of the same species respond differently to the conditions of the growth environment and also to stress factors. As a matter of fact, similar results have been obtained in various studies (Yigit et al., 2016; Sevik and Cetin, 2016; Bozdogan Sert et al., 2019; Sevik et al., 2019).

The correlation analyses performed in this study noted significant relationships between stomatal characteristics as was previously described by Cetin et al. (2017).

\section{Conclusions}

The variation of micromorphological characteristics detected on the leaves depending on growth conditions was investigated in this study. Scanning electron microscopy provides very high zoom levels thanks to high-resolution imaging techniques. Therefore, it is possible to obtain morphological, structural and elemental information from plants under these high zoom levels. The data obtained this way has the potential of being used in many areas such as determination of plant stress level, genetic variation studies, and determination of optimal plant growth conditions. However, in order for these characteristics to be effectively used in these specified areas, similar studies need to be replicated and diversified in different areas. The data in this study indicated a distinct morphological shift in size as trees are exposed to drier conditions, an indication that localized adaptation responses to stress can be observed using measurements. In particular, the studies to be done in natural populations where microclimatic conditions and human effects are absent or limited can provide much more reliable data.

\section{REFERENCES}

[1] Banon, S., Fernandez, J. A., Franco, J. A., Torrecillas, A., Alarcón, J. J., Sánchez-Blanco, M. J. (2004): Effects of water stress and night temperature preconditioning on water relations and morphological and anatomical changes of Lotus creticus plants. - Scientia Horticulture 101(3): 333-342. https://doi.org/10.1016/j.scienta.2003.11.007.

[2] Bosabalidis, A. M., Kofidis, G. (2002): Comparative effects of drought stress on leaf anatomy of two olive cultivars. - Plant Science 163(2): 375-379. https://doi.org/10.1016/S0168-9452(02)00135-8.

[3] Bozdogan Sert, E., Turkmen, M., Cetin, M. (2019): Heavy metal accumulation in rosemary leaves and stems exposed to traffic-related pollution near Adana-İskenderun Highway (Hatay, Turkey). - Environmental Monitoring and Assessment 191: 553. https://rd.springer.com/article/10.1007/s10661-019-7714-7

[4] Cetin, M. (2015): Evaluation of the sustainable tourism potential of a protected area for landscape planning: a case study of the ancient city of Pompeipolis in Kastamonu. International Journal of Sustainable Development \& World Ecology 22(6): 490-495. https://doi.org/10.1080/13504509.2015.1081651.

[5] Cetin, M. (2016): Changes in the amount of chlorophyll in some plants of landscape studies. - Kastamonu University Journal of Forestry Faculty 16(1): 239-245. http://dergipark.ulakbim.gov.tr/kastorman/article/view/5000176824/5000167063.

[6] Cetin, M., Sevik, H. (2016): Evaluating the recreation potential of Ilgaz Mountain National Park in Turkey. - Environmental Monitoring and Assessment 188(1): 52. https://doi.org/10.1007/s10661-015-5064-7. 
[7] Cetin, M., Sevik, H., Saat, A. (2017): Indoor air quality: the samples of Safranbolu Bulak Mencilis Cave. - Fresenius Environmental Bulletin 26(10): 5965-5970.

[8] Cetin, M., Adiguzel, F., Gungor, S., Kaya, E., Sancar, M. S. (2019): Evaluation of thermal climatic region areas in terms of building density in urban management and planning for Burdur, Turkey. - Air Quality Atmosphere \& Health 12 (9): 1103-1112. https://link.springer.com/content/pdf/10.1007\%2Fs11869-019-00727-3.pdf

[9] Cetin, M. (2019): The effect of urban planning on urban formations determining bioclimatic comfort area's effect using satellitia imagines on air quality: a case study of Bursa city. - Air Quality, Atmosphere \& Health 2019: 1-13. https://doi.org/10.1007/s11869-019-00742-

4. https://rd.springer.com/article/10.1007/s11869-019-00742-4

[10] Dunlap, J. M., Stettler, R. F. (2001): Variation in leaf epidermal and stomatal traits of Populus trichocarpa from two transects across the Washington Cascades. - Canadian Journal of Botany 79(5): 528-536. https://doi.org/10.1139/b01-029.

[11] Ferris, R., Nijs, I., Beaeghe, T., Impens, I. (1996): Elevated $\mathrm{CO}_{2}$ and temperature have different effects on leaf anatomy of perennial ryegrass in spring and summer. - Annals of Botany 78: 489-497. https://doi.org/10.1006/anbo.1996.0146.

[12] Galmés, J., Flexas, J., Savé, R., Medrano, H. (2007): Water relations and stomatal characteristics of Mediterranean plants with different growth forms and leaf habits: responses to water stress and recovery. - Plant and Soil 290(1): 139-155. https://doi.org/10.1007/s11104-006-9148-6.

[13] Guerfel, M., Baccouri, O., Boujnah, D., Chaïbi, W., Zarrouk, M. (2009): Impacts of water stress on gas exchange, water relations, chlorophyll content and leaf structure in the two main Tunisian olive (Olea europaea L.) cultivars. - Scientia Horticulture 119(3): 257263. https://doi.org/10.1016/j.scienta.2008.08.006.

[14] Guney, K., Cetin, M., Sevik, H., Guney, K. B. (2016): Influence of germination percentage and morphological properties of some hormones practice on Lilium martagon L. seeds. - Oxidation Communications 39(1-II): 466-474.

[15] Guney, K., Cetin, M., Guney, K. B., Melekoglu, A. (2017): The effects of some hormones applications on Lilium martagon L. germination and morphological characters. - Polish Journal of Environmental Studies 26(6): 2533-2538. http://www.pjoes.com/pdf/26.6/Pol.J.Environ.Stud.Vol.26.No.6.2533-2538.pdf.

[16] Kaya, L. G., Cetin, M., Doygun, H. (2009): A holistic approach in analyzing the landscape potential: Porsuk Dam Lake and its environs, Turkey. - Fresenius Environmental Bulletin 18(8): 1525-1533.

[17] Maiti, R., Rodríguez, H. G., Rodríguez, P. C., Balboa, J. G., Moncivais, M., Tijerina, H. A. D., Kumari, A. (2016): Leaf surface anatomy in some woody plants from northeastern Mexico. - Pakistan Journal of Botany 48(5): 1825-1831. https://www.pakbs.org/pjbot/PDFs/48(5)/09.pdf.

[18] Pearce, D. W., Millard, S., Bray, D. F., Rood, S. B. (2006): Stomatal characteristics of riparian poplar species in a semi-arid environment. - Tree Physiology 26(2): 211-218. https://doi.org/10.1093/treephys/26.2.211.

[19] Romero-Aranda, R., Soria, T., Cuartero, J. (2001): Tomato plant-water uptake and plantwater relationships under saline growth conditions. - Plant Sci 160(2): 265-272. https://doi.org/10.1016/S0168-9452(00)00388-5.

[20] Sevik, H., Cetin, M. (2015): Effects of water stress on seed germination for select landscape plants. - Polish Journal of Environmental Studies 24(2): 689-693. http://www.pjoes.com/pdf/24.2/Pol.J.Environ.Stud.Vol.24.No.2.689-693.pdf.

[21] Sevik, H., Cetin, M. (2016): Evaluation of topiary applications and problems: a case study of Kastamonu. - International Journal of Multidisciplinary Thought 05(05): 45-50.

[22] Sevik, H., Cetin, M., Kapucu, O. (2016): Effect of light on young structures of Turkish Fir (Abies nordmanniana subsp. bornmulleriana). - Oxidation Communications 39(1-II): 485-492. 
[23] Sevik, H., Cetin, M., Kapucu, O., Aricak, B., Canturk, U. (2017): Effects of light on morphologic and stomatal characteristics of Turkish fir needles (Abies nordmanniana subsp. Bornmulleriana Mattf.). - Fresenius Environmental Bulletin 26(11): 6579-6587.

[24] Sevik, H., Cetin, M., Ozel, H. B., Pinar B. (2019): Determining toxic metal concentration changes in landscaping plants based on some factors. Air Quality Atmosphere \& Health 12(8): 983-991. https://link.springer.com/content/pdf/10.1007\%2Fs11869-019-007175.pdf

[25] Xu, Z., Zhou, G. (2008): Responses of leaf stomatal density to water status and its relationship with photosynthesis in a grass. - J Exp Bot 59(12): 3317-3325. https://doi.org/10.1093/jxb/ern185.

[26] Yigit, N., Sevik, H., Cetin, M., Kaya, N. (2016): Determination of the effect of drought stress on the seed germination in some plant species. - In: Rahman, I. M. M., Begum, Z. A., Hasegawa, H. (eds.) Water Stress in Plants. Chap. 3. InTech, Rijeka, pp. 43-62. 